\title{
Detection of SHOX2 DNA methylation by methylation-specific PCR in non-small cell lung cancer
}

\author{
Hongxiang Feng ${ }^{1 \#}$, Weipeng Shao ${ }^{2 \#}$, Lanfang Du ${ }^{3 \#}$, Xin Qing ${ }^{4}$, Zhenrong Zhang ${ }^{1}$, Chaoyang Liang ${ }^{1}$, \\ Deruo Liu ${ }^{1}$
}

${ }^{1}$ Department of Thoracic Surgery, China-Japan Friendship Hospital, Beijing, China; ${ }^{2}$ Department of Thoracic Surgery, Peking University ChinaJapan Friendship School of Clinical Medicine and China-Japan Friendship Hospital, Beijing, China; ${ }^{3}$ Department of Emergency, Peking University Third Hospital, Beijing, China; ${ }^{4}$ Department of Pathology, Harbor-UCLA Medical Center, Torrance, CA, USA

Contributions: (I) Conception and design: W Shao, H Feng, L Du, D Liu; (II) Administrative support: D Liu, X Qing; (III) Provision of study materials or patients: All authors; (IV) Collection and assembly of data: W Shao, H Feng, L Du; (V) Data analysis and interpretation: W Shao, H Feng, L Du; (VI) Manuscript writing: All authors; (VII) Final approval of manuscript: All authors.

\#These authors contributed equally to this work.

Correspondence to: Deruo Liu. Department of Thoracic Surgery, China-Japan Friendship Hospital, No. 2, Yinghua, East Rd, Beijing, China. Email: deruoliu@163.com.

Background: Lung cancer is the leading cause of cancer-related death worldwide. Short stature homeobox 2 (SHOX2) methylation detected by real-time polymerase chain reaction (PCR) has recently been demonstrated to be a potential biomarker in the diagnosis of lung cancer. However, more cost-effective methods are still needed to help cancer detection in the early stage of lung cancer. The aim of this study was to examine the methylation status of the SHOX2 gene and to investigate its diagnostic value in non-small cell lung cancer (NSCLC) patients.

Methods: A total of 89 Chinese NSCLC patients and 9 non-tumor patients was enrolled in this study. The methylation status of SHOX2 gene in NSCLC tumor tissues/corresponding non-neoplastic lung tissues and lung tissues from non-tumor patients was examined by methylation-specific PCR (MSP).

Results: We found that SHOX2 methylation was significantly associated with NSCLC (P=0.003). We also analyzed the correlation of SHOX2 methylation with clinicopathological variables including sex, age, tumor pathologic classification, tumor differentiation degree, TNM stage, T stage, and nodal status, and found no significant correlation between them.

Conclusions: These results suggested that $S H O X 2$ gene methylation was closely associated with lung carcinogenesis. Thus, SHOX2 methylation could be used as a potential marker to help NSCLC detection. MSP might be used as a cost-effective method alternative to real-time PCR in detection of SHOX2 methylation in the early diagnosis of NSCLC.

Keywords: Stature homeobox 2 methylation (SHOX2 methylation); non-small cell lung cancer (NSCLC); diagnosis; methylation-specific PCR (MSP)

Submitted Feb 06, 2020. Accepted for publication Aug 21, 2020.

doi: $10.21037 /$ tcr-20-887

View this article at: http://dx.doi.org/10.21037/tcr-20-887

\section{Introduction}

Lung cancer is the leading cause of cancer-related deaths worldwide (1). In China, lung cancer is the most prevalent cancer type and accounted for $25.2 \%$ and $29.5 \%$ of the total cancer incidence and mortality in 2012, respectively (2). Over one million people die from lung cancer globally every year, among which approximately 0.6 million are from China. Worse yet, the incidence of lung cancer is still increasing in China due to the high prevalence of cigarette 
use and other factors (3).

Non-small cell lung cancer (NSCLC) accounts for approximately $85 \%$ of all lung cancers and carries a dismal 5 -year survival rate of $15 \%$ (3). Nevertheless, the International Early Lung Cancer Action Program Investigators reported that, among 302 participants with clinical stage I lung cancer who underwent surgical resection within 1 month after diagnosis, the survival rate was $92 \%$ (4). These results suggest that timely detection of lung cancer and appropriate treatment may prevent or interrupt cancer progression and improve overall survival rate. However, more than $75 \%$ of lung cancer patients are diagnosed at a locally advanced stage or with metastatic disease, partially due to the lack of an effective screening program for early detection (5). Therefore, simple, safe, and cost-effective methods to aid in early detection of lung cancer are greatly needed.

Tumor markers are molecules specifically expressed by tumor cells or produced by the host in response to tumors. Epigenetic changes of certain genes, such as DNA methylation, could occur at early stage of carcinogenesis, thus could be used as a type of tumor marker. DNA methylation based diagnostic devices has been used in screening of malignant diseases including colorectal cancer (6). SHOX2 gene is located on human chromosome 3. SHOX2 gene is widely expressed in tissue including skeleton, branchial arches, heart tissue and central nervous system (7). SHOX2 methylation is closely related to tumor occurrence and progression. In colorectal cancer, SHOX2 methylation could be used as a powerful biomarker for cancer screening and post-therapeutic monitoring (8). SHOX2 gene methylation status could also be used as potent prognostic parameter for predicting patient survival in lower-grade glioma patients (9). Recently, Dietrich et al. reported that SHOX2 methylation is a reliable biomarker for the diagnosis of lung cancer (10-14). Based on this potential, SHOX2 methylation has been developed as a commercially available assay, the Epi proLung BL Reflex Assay, for early lung cancer detection (13).

Specific DNA methylation can be measured by several polymerase chain reaction (PCR)-based methods, including methylation-specific PCR (MSP) and real-time quantitative PCR. The aforementioned commercial SHOX2 methylation assay detects SHOX2 methylation through the generation of bisulfate-converted template DNA followed by real-time PCR using TaqMan probes (13). While this is sensitive and quantitative, it is also relatively expensive.
Compared with real-time PCR-based methods, MSP is much more cost-effective. It is also fast, sensitive, and specific, and has been widely used for DNA methylation analyses $(15,16)$. Therefore, we chose to investigate the diagnostic value of SHOX2 methylation detection by MSP in lung cancer as this method may reduce costs and thus may facilitate the use of SHOX2 methylation in large-scale lung cancer screening, especially in developing countries where cost is a limiting factor. Specifically, we examined SHOX2 methylation by the MSP method in tumor tissue and corresponding non-tumor lung tissue from a cohort of Chinese NSCLC patients, and further analyzed the diagnostic value of SHOX2 methylation measured by MSP in NSCLC detection. We present the following article in accordance with the STARD reporting checklist (available at http://dx.doi.org/10.21037/tcr-20-887).

\section{Methods}

\section{Patients}

The study was conducted in accordance with the Declaration of Helsinki (as revised in 2013). The patients underwent surgery after providing informed consent, and the requirement for the individual consent of patients whose records were evaluated was waived because they were de-identified in the study. The study was approved by institutional ethics board of China-Japan Friendship Hospital (No. 2018-13-K08). A total of 89 NSCLC patients and 9 non-tumor patients were included in this study.

Clinicopathological characteristics of the participating patients with cancer or non-cancer are presented in Tables 1 and 2, respectively. All tumors in these patients were completely resected (R0 category) by surgery. Additionally, histologically normal lung tissue specimens obtained at surgery from 9 patients with no evidence of cancer were used as a control group (including 8 patients with pulmonary bulla and 1 patient with benign tumor). In the control group, 6 patients were men and 6 were under 60 years old.

\section{Tissue acquisition and DNA extraction}

Tissues for DNA analysis were obtained immediately after lung resection before starting mediastinal lymphadenectomy and were frozen in liquid nitrogen. Tissues were analyzed as tumors or uninvolved lung tissues taken from the farthest 
Table 1 Clinicopathological characteristics of 89 non-small cell lung cancer patients

\begin{tabular}{|c|c|}
\hline Characteristics & $N(\%)$ \\
\hline \multicolumn{2}{|l|}{ Sex } \\
\hline Male & $63(70.8)$ \\
\hline Female & $26(29.2)$ \\
\hline \multicolumn{2}{|l|}{ Age* $^{*}$} \\
\hline$<60$ & $42(47.2)$ \\
\hline$\geq 60$ & $47(52.8)$ \\
\hline \multicolumn{2}{|l|}{ Pathologic classification } \\
\hline Squamous cell carcinoma & $34(38.2)$ \\
\hline Adenocarcinoma & $47(52.8)$ \\
\hline Other & $8(9.0)$ \\
\hline \multicolumn{2}{|l|}{ Differentiation degree } \\
\hline Undifferentiated/poorly & $39(43.8)$ \\
\hline Moderately/well & $50(56.2)$ \\
\hline \multicolumn{2}{|l|}{ TNM stage } \\
\hline $\mathrm{I} / \mathrm{II}$ & $52(58.4)$ \\
\hline III/IV & $37(41.6)$ \\
\hline \multicolumn{2}{|l|}{ T stage } \\
\hline $\mathrm{T} 1 / 2$ & $58(65.2)$ \\
\hline T3/4 & $31(34.8)$ \\
\hline \multicolumn{2}{|l|}{ Nodal status } \\
\hline No & $39(43.8)$ \\
\hline $\mathrm{N}+$ & $50(56.2)$ \\
\hline
\end{tabular}

*, age according to median value of 60 years (range 36-78). T, tumor size; $\mathrm{N}$, total number of patients.

Table 2 Clinicopathological characteristics of 9 non-cancer patients

\begin{tabular}{lc}
\hline Characteristics & $\mathrm{N}$ \\
\hline Sex & 6 \\
Male & 3 \\
Female & \\
Age & 6 \\
$<60$ & 6 \\
$\geq 60$ & 3 \\
\hline
\end{tabular}

distance from tumors. Ten $\mu \mathrm{m}$ thick frozen sections were taken from blocks of tumor tissues and stained with $\mathrm{H} \& \mathrm{E}$ for histopathological evaluation. Sections were pooled for analysis from areas of estimated $75 \%$ malignant cells. Genomic DNA was isolated from frozen tissue by standard methods of proteinase $\mathrm{K}$ digestion and phenol-chloroform extraction using Tiangen Cells and Tissue DNA Isolation Kit (Tiangen Biotech Co., LTD, Beijing, China) according to the manufacturer's instructions.

\section{Detection of SHOX2 methylation using MSP}

A total of $500 \mathrm{ng}$ genomic DNA extracted from tissue samples was modified by sodium bisulfite with DNA Methylation Detection Kit (BioChain, USA) according to the manufacturer's instructions. $7 \mu \mathrm{L}$ modified DNA was used for PCR in a total reaction volume of $25 \mu \mathrm{L}$. PCR program was set as 35 cycles of melting $\left(95^{\circ} \mathrm{C}\right.$ for $\left.30 \mathrm{~s}\right)$, annealing $\left(58^{\circ} \mathrm{C}\right.$ for $\left.30 \mathrm{~s}\right)$ and extension $\left(72{ }^{\circ} \mathrm{C}\right.$ for $\left.30 \mathrm{~s}\right)$. The $25 \mu \mathrm{L}$ reaction mixture contained $1 \times$ PCR Buffer ( $\mathrm{Mg}^{2+}$ Plus), $200 \mu \mathrm{M}$ of each dNTP, $0.5 \mu \mathrm{M}$ forward primer, $0.5 \mu \mathrm{M}$ reverse primer, and 0.5 unit of GoTaq Hot Start Polymerase (Promega, USA). PCR products were separated in $3 \%$ agarose gel supplemented with ethidium bromide. DNA was visualized under UV illumination. SHOX2 was recorded as methylated if MSP amplification products were detected in both reactions with unmethylation and methylation primers, or with methylation primers only. The primer sequences are as follows:

* Unmethylation-specific primers: TGTATGAGTATAGGTGTTTATG (forward), AAAACAATTACTTTCACCCA (reverse);

* Methylation-specific primers : CGTACGAGTATAGGCGTTTACG (forward), AAAACGATTACTTTCGCCCG (reverse).

\section{Statistical analysis}

Statistical comparisons were performed using either the $\chi^{2}$ test or Fisher's exact test, as appropriate. Student's $t$-test was performed to assess the statistical significance between the mean values. All data were analyzed by SPSS software (SPSS Statistics 19, Rel. 19.0. 2010. Armonk, NY: IBM Corp.). $\mathrm{P}$ values less than 0.05 were considered to be statistically significant. 


\section{Results}

\section{The characteristics of the NSCLC patients}

A total of 89 Chinese NSCLC patients were included in this study, consisting of $63(70.8 \%)$ men and $26(29.2 \%)$ women. Forty-two (47.2\%) patients were younger than and $47(52.8 \%)$ patients were older than the age of 60 , which was the median value (range 36-78) of the cohort of patients. Based on the pathologic classification, 34 (38.2\%) patients had squamous cell carcinomas, 47 (52.8\%) had adenocarcinomas, and $8(9.0 \%)$ had tumors of other histological types. The primary tumors were graded histopathologically into undifferentiated/poorlydifferentiated tumors and moderately/well-differentiated tumors, with $39(43.8 \%)$ patients classified into the former group and $50(56.2 \%)$ into the latter one. Fifty-two (58.4\%) patients had stage I/II tumors and 37 (41.6\%) had stage III/ IV tumors. Fifty-eight (65.2\%) tumors were graded at T1/ T2 stage and $31(34.8 \%)$ were at T3/4 stage. Tumors in 39 (43.8\%) patients had not metastasized while 50 (56.2\%)

Table 3 SHOX2 DNA methylation in non-small cell lung cancer and corresponding non-neoplastic lung tissues as well as in lung tissues of non-cancer patients

\begin{tabular}{lccc}
\hline & \multicolumn{2}{c}{ Methylation status } & \multirow{2}{*}{$\mathrm{P}^{*}$} \\
\cline { 2 - 3 } Variable & Tumor & $\begin{array}{c}\text { Non-neoplastic } \\
\text { lung tissue }\end{array}$ & \\
\hline NSCLCs: SHOX2 M/ & $83 / 6$ & $6 / 83$ & 0.003 \\
U (n=89) & & & \\
Non-cancer patients: & $0 / 9$ & \\
SHOX2 M/U $(n=9)$ & & & \\
\hline
\end{tabular}

*, statistical analysis performed by Fisher's or $\mathrm{X}^{2}$ test, comparing the number of patients with methylated gene (M) with the number of unmethylated gene $(U)$ detected. $M$, number of patients with methylation detected. $U$, number of patients without methylation detected. NSCLC, non-small cell lung cancer. patients had nodal metastasis.

\section{Correlation of SHOX2 methylation with NSCLC tumor tissues}

We determined the methylation status of SHOX2 in tumor tissues and paired non-neoplastic lung tissues of 89 Chinese NSCLC patients and in the lung tissues of 9 noncancer patients using MSP (Table 3). Representative DNA gel electrophoresis image of polymerase chain reaction products was showed on the Figure 1. SHOX2 methylation was detected in tumor tissue samples from 83 of the 89 NSCLC patients, with an occurrence of $93.3 \%$. Conversely, SHOX2 methylation was found in only $6(6.7 \%)$ of the paired non-neoplastic lung tissue samples. Fisher's test showed that there is a significant correlation between SHOX2 methylation and tumor tissue, with a $\mathrm{P}$ value of 0.003. We did not detect SHOX2 methylation in the lung tissues of any of the 9 non-tumor patients. These results suggest a promising diagnostic value of detection SHOX2 methylation by MSP in NSCLC patients.

\section{Association of SHOX2 methylation with clinicopathological variables in Patients with NSCLCs}

We also analyzed the association between SHOX2 methylation and the clinicopathological variables in NSCLC patients using Fisher's or $\chi^{2}$ test (Table 4). Results showed that there are no obvious statistically significant correlations between SHOX2 methylation and any of the collected clinicopathological variables including sex, age, tumor pathologic classification, tumor differentiation degree, TNM stage, T stage and nodal status. These results suggest that SHOX2 methylation is significantly associated with NSCLC tumor tissue regardless of clinicopathological status. These results further support the diagnostic value of SHOX2 methylation in NSCLC patients.

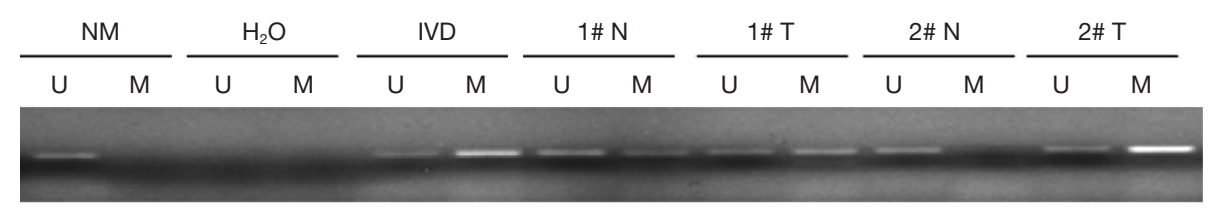

Figure 1 Representative DNA gel electrophoresis image of polymerase chain reaction products. NM, lymphocyte DNA as unmethylation positive control; IVD, in vitro methylated lymphocyte DNA as methylation positive control; T, tumor tissue; N, non-neoplastic lung tissue; U, MSP with unmethylation primers; M, MSP with methylation primers; 1\#, 2\# represent different non-small cell lung cancer patients. 
Table 4 Association of SHOX2 DNA methylation detected in nonsmall cell lung cancer patients with clinicopathological variables using Fisher's or $\chi^{2}$ test

\begin{tabular}{|c|c|c|}
\hline \multirow[b]{2}{*}{ Characteristics } & \multicolumn{2}{|c|}{ SHOX2 M/U } \\
\hline & Tumor & $\begin{array}{c}\text { Non-neoplastic } \\
\text { lung tissue }\end{array}$ \\
\hline \multicolumn{3}{|l|}{ Sex } \\
\hline Male & $58 / 5$ & $4 / 59$ \\
\hline Female & $25 / 1$ & $2 / 24$ \\
\hline $\mathrm{P}^{\mathrm{a}}$ & 0.67 & 1.00 \\
\hline \multicolumn{3}{|l|}{$\mathrm{Age}^{*}$} \\
\hline$<60$ & $41 / 1$ & $2 / 40$ \\
\hline$\geq 60$ & $42 / 5$ & $4 / 43$ \\
\hline $\mathrm{P}^{\mathrm{a}}$ & 0.21 & 0.68 \\
\hline \multicolumn{3}{|l|}{ Pathologic classification } \\
\hline Squamous cell carcinoma & $32 / 2$ & $2 / 32$ \\
\hline Adenocarcinoma & $43 / 4$ & $3 / 44$ \\
\hline Other & $8 / 0$ & $1 / 7$ \\
\hline $\mathrm{P}^{\mathrm{a}}$ & 0.65 & 0.79 \\
\hline \multicolumn{3}{|l|}{ Differentiation degree } \\
\hline Undifferentiated/poorly & $38 / 1$ & $1 / 38$ \\
\hline Moderately/well & $45 / 5$ & $5 / 45$ \\
\hline$P^{a}$ & 0.23 & 0.23 \\
\hline \multicolumn{3}{|l|}{ TNM stage } \\
\hline $\mathrm{I} / \mathrm{II}$ & $48 / 4$ & $5 / 47$ \\
\hline III/IV & $35 / 2$ & $1 / 36$ \\
\hline$P^{a}$ & 1.00 & 0.39 \\
\hline \multicolumn{3}{|l|}{ T stage } \\
\hline $\mathrm{T} 1 / 2$ & $55 / 3$ & $4 / 54$ \\
\hline T3/4 & $28 / 3$ & $2 / 29$ \\
\hline$P^{a}$ & 0.42 & 1.00 \\
\hline \multicolumn{3}{|l|}{ Nodal status } \\
\hline NO & $36 / 3$ & $3 / 36$ \\
\hline $\mathrm{N}+$ & $47 / 3$ & $3 / 47$ \\
\hline$P^{a}$ & 1.00 & 1.00 \\
\hline
\end{tabular}

$\mathrm{P}^{\mathrm{a}}$ statistical analysis performed by Fisher's or $\chi^{2}$ test, comparing the number of patients with methylated SHOX2 (M) with the number of unmethylated SHOX2 (U) detected. *, age according to median value of 60 years (range $36-78$ ). M, number of patients with methylation detected. $U$, number of patients without methylation detected.

\section{Discussion}

In this study, we applied MSP to detect the methylation status of the SHOX2 gene in tumor tissues and corresponding non-tumor lung tissues in 89 Chinese NSCLC patients and found that $\mathrm{SHOX} 2$ methylation is significantly correlated with NSCLC. This findings are consistent with prior studies $(10,11)$ and support that SHOX2 methylation may be a useful biomarker for lung cancer diagnosis.

At present, both qualitative and quantitative methods are used to measure DNA methylation of specific genes. Despite the lack of quantitative information obtained from real-time PCR based methods, MSP is widely applied in clinical researches for DNA methylation because it is fast, simple, specific, requires resources commonly available in a molecular genetics laboratory, and is very cost-effective (16-22). MSP is also sensitive in that it can detect as low as $0.1 \%$ (50 pg of methylated DNA out of $50 \mathrm{ng}$ of total DNA) to $1 \%(0.1 \mathrm{ng}$ of methylated DNA out of $10 \mathrm{ng}$ of total DNA) methylated alleles (23-25). By using Quantitative HeavyMethyl (HM) real-time PCR, Dietrich et al. reported hypermethylation of the SHOX2 locus in tumor tissue in $96 \%$ of tumors from a group of 55 patients with lung cancer (12), where as in our current study, SHOX2 methylation was detected in $93.3 \%$ tumor tissues from the cohort of 89 NSCLC patients. These results suggest that MSP may be used as a cost-effective alternative in detection of SHOX2 methylation in the diagnosis of NSCLC. The development of this simple, low-cost MSP method may facilitate the wide use of detection of SHOX2 methylation in large-scale NSCLC early screening, especially in developing countries.

DNA methylation is an important epigenetic modification in cancer. Aberrant methylation of the promoter region in a specific gene causes gene silencing. Hence, methylation of tumor suppressor genes is an early and frequent event during carcinogenesis (26). SHOX2 is a member of the homeobox family and plays important roles in embryonic morphogenesis, heart, skeleton, and nervous system development (27-35). In addition to its involvement in early development, human SHOX2 has been found to be expressed in tumors including neuroblastomas and breast cancer $(36,37)$. Although SHOX2 methylation is demonstrated to be an excellent biomarker in lung cancer diagnosis, whether the SHOX2 gene qualifies as a tumor suppressor gene is not clear. Interestingly, unlike hypermethylated tumor suppressor genes that are down-regulated in tumors, elevated SHOX2 expression 
was reported to be associated with tumor recurrence of hepatocellular carcinoma (38). However, the mechanism of increased expression of SHOX2 in hepatocellular carcinoma is unknown. Dietrich et al. found that SHOX2 was expressed at similar transcriptional levels in tumor tissue and normal adjacent tissue from lung cancer patients (12). The authors further reported that SHOX2 methylation was correlated with $S H O X 2$ gene amplification (12) caused by genomic gain of chromosome $3 \mathrm{q}$ involving theSHOX2 gene, which has been recognized as one of the most prevalent and significant chromosomal rearrangements in lung cancer $(39,40)$. Therefore, the up-regulation caused by SHOX2 gene amplification may counteract the negative regulatory effect associated with SHOX2 methylation, and thus no significant expression change was detected between lung tumor and paired non-tumor lung tissues. Furthermore, the consistency of SHOX2 methylation observed in lung cancer tissue from Chinese patient samples reported herein and from Dietrich's work in European people (12) suggests that the epigenetic modification of SHOX2 seems similar in populations with different genetic backgrounds. The conflicting results of the expression of SHOX2 in hepatocellular carcinoma and lung cancer indicate that a lot of work remains to be done to clarify the relationship between SHOX2 expression and methylation in different tumors, as well as the molecular mechanisms of SHOX2 regulation.

Appropriate usage of SHOX2 methylation to aid in the early detection and diagnosis of lung cancer will facilitate timely treatment of lung cancer patients to improve their survival. Our results demonstrated that the MSP method provides comparable results in detection of SHOX2 methylation when compared with the much more expensive real-time PCR based method.

\section{Acknowledgments}

Funding: None.

\section{Footnote}

Reporting Checklist: The authors have completed the STARD reporting checklist. Available at http://dx.doi.org/10.21037/ tcr-20-887

Data Sharing Statement: Available at http://dx.doi. org/10.21037/tcr-20-887
Conflicts of Interest: All authors have completed the ICMJE uniform disclosure form (available at http://dx.doi. org/10.21037/tcr-20-887). The authors have no conflicts of interest to declare.

Ethical Statement: The authors are accountable for all aspects of the work in ensuring that questions related to the accuracy or integrity of any part of the work are appropriately investigated and resolved. The study was conducted in accordance with the Declaration of Helsinki (as revised in 2013). The study was approved by institutional ethics board of China-Japan Friendship Hospital (No. 2018-13-K08). The patients underwent surgery after providing informed consent, and the requirement for the individual consent of patients whose records were evaluated was waived because they were de-identified in the study.

Open Access Statement: This is an Open Access article distributed in accordance with the Creative Commons Attribution-NonCommercial-NoDerivs 4.0 International License (CC BY-NC-ND 4.0), which permits the noncommercial replication and distribution of the article with the strict proviso that no changes or edits are made and the original work is properly cited (including links to both the formal publication through the relevant DOI and the license). See: https://creativecommons.org/licenses/by-nc-nd/4.0/.

\section{References}

1. Jemal A, Bray F, Center MM, et al. Global cancer statistics. CA Cancer J Clin 2011;61:69-90.

2. Ferlay J, Soerjomataram I, Ervik M, et al. GLOBOCAN 2012 v1.1, Cancer Incidence and Mortality Worldwide: IARC CancerBase No. 11. Int J Cancer 2015;136:E359-86.

3. Molina JR, Yang P, Cassivi SD, et al. Non-small cell lung cancer: epidemiology, risk factors, treatment, and survivorship. Mayo Clin Proc 2008;83:584-94.

4. Henschke CI, Yankelevitz DF, Libby DM, et al. Survival of patients with stage I lung cancer detected on CT screening. N Engl J Med 2006;355:1763-71.

5. Mikeska T, Bock C, Do H, et al. DNA methylation biomarkers in cancer: progress towards clinical implementation. Expert Rev Mol Diagn 2012;12:473-87.

6. Ahlquist DA, Zou H, Domanico M, et al. Next-generation stool DNA test accurately detects colorectal cancer and large adenomas. Gastroenterology 2012;142:248-56; quiz e25-6. 
7. Clement-Jones, $M$. The short stature homeobox gene SHOX is involved in skeletal abnormalities in Turner syndrome. Hum Mol Genet 2000;9:695-702.

8. Bergheim J, Semaan A, Gevensleben H, et al. Potential of quantitative SEPT9 and SHOX2 methylation in plasmatic circulating cell-free DNA as auxiliary staging parameter in colorectal cancer: a prospective observational cohort study. Br J Cancer 2018;118:1217-28.

9. Zhang YA, Zhou Y, Luo X, et al. SHOX2 is a Potent Independent Biomarker to Predict Survival of WHO Grade II-III Diffuse Gliomas. EBioMedicine 2016;13:80-9.

10. Schmidt B, Liebenberg V, Dietrich D, et al. SHOX2 DNA methylation is a biomarker for the diagnosis of lung cancer based on bronchial aspirates. BMC Cancer 2010;10:600.

11. Kneip C, Schmidt B, Seegebarth A, et al. SHOX2 DNA Methylation Is a Biomarker for the Diagnosis of Lung Cancer in Plasma. J Thorac Oncol 2011;6:1632-8.

12. Schneider KU, Dietrich D, Fleischhacker M, et al. Correlation of SHOX2 Gene Amplification and DNA Methylation in Lung Cancer Tumors. BMC Cancer 2011;11:102.

13. Dietrich D, Dietrich D, Kneip C, et al. Performance evaluation of the DNA methylation biomarker SHOX2 for the aid in diagnosis of lung cancer based on the analysis of bronchial aspirates. Int J Oncol 2012;40:825-32.

14. Darwiche K, Zarogoulidis P, Baehner K, et al. Assessment of SHOX2 methylation in EBUS-TBNA specimen improves accuracy in lung cancer staging. Ann Oncol 2013;24:2866-70.

15. Wong IHN. Qualitative and quantitative polymerase chain reaction-based methods for DNA methylation analyses. Methods Mol Biol 2006;336:33-43.

16. Hernández HG, Tse MY, Pang SC, et al. Optimizing methodologies for PCR-based DNA methylation analysis. Biotechniques 2013;55:181-97.

17. Haroun RA, Zakhary NI, Mohamed MR, et al. Assessment of the prognostic value of methylation status and expression levels of FHIT, GSTP1 and p16 in non-small cell lung cancer in Egyptian patients. Asian Pac J Cancer Prev 2014;15:4281-7.

18. Chen H, Pan Y, Cheng ZY, et al. Hypermethylation and Clinicopathological Significance of RASAL1 Gene in Gastric Cancer. Asian Pac J Cancer Prev 2013;14:6261-5.

19. Zhai X, Li SJ. Methylation of RASSF1A and CDH13 genes in individualized chemotherapy for patients with non-small cell lung cancer. Asian Pac J Cancer Prev 2014;15:4925-8.
20. Li W, Deng J, Tang JX. Combined effects methylation of FHIT, RASSF1A and RARbeta genes on non-small cell lung cancer in the Chinese population. Asian Pac J Cancer Prev 2014;15:5233-7.

21. Yang Y, Fan YC, Gao S, et al. Methylated cysteine dioxygenase- 1 gene promoter in the serum is a potential biomarker for hepatitis B virus-related hepatocellular carcinoma. Tohoku J Exp Med 2014;232:187-94.

22. Oliver JA, Ortiz R, Melguizo C, et al. Prognostic impact of MGMT promoter methylation and MGMT and CD133 expression in colorectal adenocarcinoma. BMC Cancer 2014;14:511.

23. Herman JG, Graff JR, Myohanen S, et al. Methylationspecific PCR: a novel PCR assay for methylation status of CpG islands. Proc Natl Acad Sci U S A 1996;93:9821-6.

24. Derks S, Lentjes MH, Hellebrekers DM, et al. Methylation-specific PCR unraveled. Cell Oncol 2004;26:291-9.

25. Häfner N, Diebolder H, Jansen L, et al. Hypermethylated DAPK in serum DNA of women with uterine leiomyoma is a biomarker not restricted to cancer. Gynecol Oncol 2011;121:224-9.

26. Herman JG, Baylin SB. Gene Silencing in Cancer in Association with Promoter Hypermethylation. N Engl J Med 2003;349:2042-54.

27. Liu $\mathrm{H}$, Chen $\mathrm{CH}, \mathrm{Ye} W$, et al. Phosphorylation of Shox2 is required for its function to control sinoatrial node formation. J Am Heart Assoc 2014;3:e000796.

28. Aza-Carmona M, Barca-Tierno V, Hisado-Oliva A, et al. NPPB and ACAN, two novel SHOX2 transcription targets implicated in skeletal development. PLoS One 2014;9:e83104.

29. Glaser A, Arora R, Hoffmann S, et al. Tbx4 interacts with the short stature homeobox gene Shox2 in limb development. Dev Dyn 2014;243:629-39.

30. Hashem SI, Lam ML, Mihardja SS, et al. Shox2 Regulates the Pacemaker Gene Program in Embryoid Bodies. Stem Cells Dev 2013;22:2915-26.

31. Sun C, Zhang T, Liu C, et al. Generation of Shox2Cre allele for tissue specific manipulation of genes in the developing heart, palate, and limb. Genesis 2013;51:515-22.

32. Liu H, Espinoza-Lewis RA, Chen C, et al. The Role of Shox2 in SAN Development and Function. Pediatr Cardiol 2012;33:882-9.

33. Abdo H, Li L, Lallemend F, et al. Dependence on the transcription factor Shox 2 for specification of sensory neurons conveying discriminative touch. Eur J Neurosci 
2011;34:1529-41.

34. Puskaric S, Schmitteckert S, Mori AD, et al. Shox2 mediates Tbx 5 activity by regulating Bmp4 in the pacemaker region of the developing heart. Hum Mol Genet 2010;19:4625-33.

35. Espinoza-Lewis RA, Yu L, He F, et al. Shox 2 is essential for the differentiation of cardiac pacemaker cells by repressing Nkx2-5. Dev Biol 2009;327:376-85.

36. Naderi A, Teschendorff AE, Barbosa-Morais NL, et al. A gene-expression signature to predict survival in breast cancer across independent data sets. Oncogene 2007;26:1507-16.

37. Ohira M, Morohashi A, Inuzuka H, et al. Expression profiling and characterization of 4200 genes cloned from

Cite this article as: Feng $\mathrm{H}$, Shao W, Du L, Qing X, Zhang Z, Liang C, Liu D. Detection of SHOX2 DNA methylation by methylation-specific PCR in non-small cell lung cancer. Transl Cancer Res 2020;9(10):6070-6077. doi: 10.21037/tcr-20-887 primary neuroblastomas: identification of 305 genes differentially expressed between favorable and unfavorable subsets. Oncogene 2003;22:5525-36.

38. Yang T, Zhang H, Cai SY, et al. Elevated SHOX2 expression is associated with tumor recurrence of hepatocellular carcinoma. Ann Surg Oncol 2013;20 Suppl 3:S644-9.

39. Dehan E, Ben-Dor A, Liao W, et al. Chromosomal aberrations and gene expression profiles in non-small cell lung cancer. Lung Cancer 2007;56:175-84.

40. Huang YT, Heist RS, Chirieac LR, et al. Genome-wide analysis of survival in early-stage non-small-cell lung cancer. J Clin Oncol 2009;27:2660-7. 